\title{
MEXICO ON A CRIMINAL TRAFFIC SCENARIO
}

\author{
B.F. Martynov, M.P. Moloeznik \\ Moscow state institute of international relations (MGIMO-University) \\ University Center for Social Sciences and Humanities of the University of Guadalajara
}

The article describes the problem of organized crime in modern Mexico. It addresses the activities of criminal clans, which profoundly evolved since the 1930s. The USMexican extensive border length and the stable demand for drugs in the United States leads to the continuous flow of illegal migrants and drugs from Mexico to the US and American firearms back to Mexico. First, the authors address the issue of interconnectedness of crime in the neighboring countries. Second, they describe the geographical distribution of crime activity. It shows the influence of organized crime on the political life oin Mexico and ways of its adaptation to law enforcement pressure, namely division and disaggregation.

The authors state that the fight against organized crime was ineffective in Mexico in 2006-2012, because it ignored political and cultural realities, it used exclusively force and almost did not involve civil society. In addition, it only increased the level of violence in the country and contributed to the growth of corruption in the ranks of law enforcement. Moreover, it increased the level of violence in the country and contributed to the growth of corruption in the ranks of law enforcement. Many of its components had a pronounced «pre-election» character, aimed at attracting the voter with the promise of an «early and decisive victory» over criminals.

The article proposes new approach to the problem of organized crime in Mexico. To start with, government should refuse to use unilateral, as well as politicized and opportunistic actions. The involvement of civic society is of ultimate importance.

Key words: Mexican organized crime, drug cartels, illegal immigration, drug traffic, US-Mexican relations. 
"State and Mafia are two powers occupying the same territory: or they make war or they make an agreement"

Paolo Borsellino (1940-1992) Italian judge assassinated by Mafia

The level of organized crime in contemporary Mexico is unbelievably high. Mexico and the United States are connected by one of the longest borders in the world $(3.200 \mathrm{~km})$, which encourages trafficking of all kind that actually began in the $19^{\text {th }}$ century and was boosted during the years of the Mexican revolution $(1910$ - 1917).

The second half of the 1920's and early 1930's, the Prohibition years in the US history, witnessed the start of Mexican smuggling of alcohol to the north ${ }^{1}$, so that by the end of the 1930's the main flow of the trafficking shifted completely to the US side of the border. It contributed to the growth and diversification of Mexican criminal cartels, which spread their activities along both sides of the border. The oldest and the most notorious one of them was the Cartel del Golfo (Cartel of the Gulf) flourishing precisely on bootlegging.

The present stage of evolving criminal activities in Mexico is shaped by extension of trafficking over two new "goods": people and drugs [8, p. 120]. This diversification has greatly increased the overall level of violence in the country. It can hardly be called simply "crime" because some big clans, such as Los Zetas and Los Caballeros Templarios among others, have characteristics of terrorist organizations, practicing executions, propagating terror, struggling to change local and municipal authorities. The wave of criminality moves to the South, spreading to the states of the country that earlier enjoyed relative political stability. The wave of criminality expands further to the South - to the Central American and Caribbean countries.

The growing migration of Mexican workers to the north brings to life different illegal facilities for border crossing: special people ("los pollos"), secret gathering points, transport and logistics services etc. The tariffs for the would-be migrants are constantly growing, increasing from about $\$ 1000$ per person in the 1990 s to $\$ 3000-20000$ (!) per person in 2014. Such facilities either merge with the bigger criminal groups, or evolve into "independent" full-scale gangs.

The newest feature in this criminal business is the juvenile traffic, when children cross the border without documents and not accompanied by parents. Only in 2014 the US border guards prevented the trafficking of around 70 thousands (!) of such transgressors ${ }^{2}$, the greater part of them originating not from Mexico, but from the other Central and South America countries. Mexico serves as a transit county for traf-

\footnotetext{
1 This phenomenon has acquired even greater size in Cuba, where the bootlegging contributed to the creation of the local criminal clans and their cooperation with the branches of the US mafia. The Cuban Revolution of the 1959 put an end to these activities in both countries.

2 González J. EEUU desbordado por la "crisis humanitaria" de los niños sin papeles. BBC Mundo. 21.06.2014. Available at: http://www.bbc.com/mundo/noticias/2014/06/140620_eeuu_crisis_humanitaria_menores_indocumentados_jg (accessed: 23.02.2017).
} 
ficking to the US, which, on the one hand, exacerbates the US - Mexican relations, and, on the other, makes it necessary for Mexico to secure its southern borders.

A substation part of trafficking in human is prostitution. Young women from Mexico are "invited" to work in night clubs and brothels on the US territory. This "industry" is especially developed in the northern states of Mexico, where disappearing and killing of women have become notorious, the most known cases being the Mexican cities of Ciudad Juarez and Veracruz ${ }^{3}$. In 2012 "white slave" trade earned Mexican criminal cartels around $\$ 10$ bln $^{4}$.

Trafficking in humans and drugs to the north is the most profitable business for Mexican criminal groups. A Russian scientist M. Chumakova notes that in the period from 2000 to 2009 the number of crimes connected with the drug traffic in Mexico has increased 2.6 times [2]. Simultaneously, Mexico and the Central American countries receive large stocks of the US firearms, which are used in the criminal wars among Mexican gangs.

Until recently around 95\% of illegal firearms confiscated in Mexico have the US origin. "The US demand for narcotics and the Mexican - for the American firearms formed the bases of the Mexican drug cartels", - notes Shannon O 'Nail of the Council for Foreign Relations [7, p. 7]. According to FBI, "the ramifications of those extremely powerful criminal gangs can be found nowadays in thousands of American cities"

Mexico differs from other Latin American countries in production of drugs. Its climatic and natural conditions allow it to cultivate both cannabis (marijuana) and opium. The newest trend is a dramatic rise in the production of the synthetic drugs, which is greater than in other Latin American countries (except Argentina). The geographic proximity to the US increases the role of Mexico as an important transit territory for the South American cocaine (from the Andean countries) [10, p. 90]. In this respect the evolution of the Mexican drug cartels from mere bootlegging structures in the 1930's to the contemporary gangster conglomerates with "diversified" business interests is illustrative of a continuous criminalization trend.

Mexico begins $21^{\text {st }}$ century with the predominance of four big drug organizations: the Gulf Cartel, Los Carrillo Fuentes, La Federación and the Arellano Felix. In 1980's and 1990's they were nothing more, than mere groups of criminals, supplying the US market with cocaine and marijuana from South America. As it turned out later they used that time to sophisticate their modus operandi and to accumulate the initial financial base for the subsequent growth.

The accumulated capital allow them to expand their influence in the informal economy and create diversified criminal social networks, including business and government bodies to protect their business. They engage in government and public af-

\footnotetext{
3 Drug violence in Mexico. Data and Analysis through 2015. Special report. Justice in Mexico. University of San Diego. Available at: https://justiceinmexico.org/wp-content/uploads/2016/04/DrugViolenceinMexico-Final-2015.pdf (accessed: 23.02.2017).

4 Pérez Salazar J.C. México y el infierno de la trata de mujeres. BBC Mundo. Available at: http://www.bbc.com/mundo/ noticias/2013/11/131111_mexico_trata_mujeres_prostitucion_jcps (accessed: 23.02.2017)

${ }_{5}^{5}$ 6. Federal Bureau of Investigation (FBI). National Drug Treatment Assessment: Emerging Trends. Washington D.C., 2011. P6.. Available at: https://www.fbi.gov/file-repository/stats-services-publications-2011-national-gang-threat-assessment2011-national-gang-threat-assessment-emerging-trends (accessed: 23.02.2017)
} 
fairs establishing networks in local communities and municipalities to safeguard their profits.

Over the last twenty-five years Colombia and Mexico are the two cases of successful criminal organizing of trafficking. Both in Mexico and Colombia the cocaine profits in the 1980s and early 1990s stimulated the growth of countries' major criminal networks and unleashed a wave of violence in them. In mid 2012 the Mexican criminal gangs began to gradually follow the Colombian pattern of dispersion and fragmentation. In 2000 the Tijuana cartel (belonging to the Arrellano Félix family) and the Juárez cartel (Carrillo Fuentes family) were the two largest and the most powerful drug trafficking organizations in Mexico. Since 2000, after the measures taken by the administration of Vicente Fox, first the Tijuana and then the Juárez entered the process of fragmentation. In their place there appeared at least four new major trafficking organizations: the Sinaloa cartel, the Familia Michocana, the Beltrán Leyva and the Los Zetas, besides other smaller and less known groups. This dispersion of criminal networks in Mexico resembles the pattern that took place in Colombia in the 1990s. [1, p. 8].

This trend if continues should be welcomed by the Mexican government, because the smaller and the less powerful groups would hardly challenge the interests of the state bureaucracy in the same manner as the greater ones usually did.

Table 1. Mexican Cartels, 2006-2010

\begin{tabular}{|l|l|l|}
\hline \multicolumn{1}{|c|}{2006} & \multicolumn{1}{|c|}{$2007-2009$} & \multicolumn{1}{|c|}{2010} \\
\hline 1. Pacífico Cartel & 1.Pacífico Cartel & 1.Pacífico Cartel \\
2. Juárez Cartel & 2. Beltrán Leyva Cartel & 2. Pacífico Sur Cartel \\
3. Tijuana Cartel & 3. Juárez Cartel & 3. Acapulco Independent Cartel \\
4. Cartel del Golfo & 4. Tijuana Cartel & 4. La Barbie Cartel \\
5. La Familia Michoacana & 5. El Teo Faction & 5. Juárez Cartel \\
6. Milenio Cartel & 6. Golfo-Zetas Cartel & 6. Tijuana Cartel \\
& 7. La Familia Michoacana & 7. El Teo Faction \\
& 8. Milenio Cartel & 8. Golfo Cartel \\
& & 9. Zetas Cartel \\
& & 10. La Familia Michoacana \\
& & 11. La Resistencia Cartel \\
& 12. Jalisco Cartel - Nueva Generación \\
\hline
\end{tabular}

Source: [3].

In 2012 the financial growth of the Mexican drug market stimulated the increase in number of organizations capable to export drugs internationally from four to nine. The information obtained from the Mexican law enforcement structures, enabled us to set out a list of them (see table 1.). It is headed now by the Sinaloa cartel and followed by the Cartel Jalisco Neva Generación (CJNG), the Beltran Leyva, the Carrillo Fuentes, the Gulf Cartel (CDG), the Los Zetas, the Arellano Felix, the Familia Michoacana and the Caballeros Templarios.

A former Attorney General Rafael Macedo de la Concha presented in 2005 to the Public Security Commission of a Mexican Senate a list of 490,000 (!) complaints related to drug sales across the country during the administration of Vicente Fox. This allowed identifying more than 10,000 retail drug points active only in Mexico City. 2,000 of them were revealed in the state of Baja California and 2,000 - in the states of Sinaloa, Chihua- 
hua, Tamaulipas and Jalisco. One thousand points were discovered in the states of Nuevo Leon, Guerrero, Quintana Roo, and about 500 - in the rest of the states of the Union' ${ }^{6}$.

\section{Spatial Dimension}

Was there any result of the "war on drugs" declared by the president F. Calderon still at play in 2006? We believe, that the results were rather untraceable. According to the latest official report of the Attorney General: "From 2014 to 2016 the organized crime groups remained in Mexico almost intact. The Jalisco Nueva Generación cartel lost its presence only in one single entity: in Mexico City. This criminal group currently maintains its presence in eight states: more than any other criminal organization in this country. Its operations seem to be highly centralized and its presence does not depend on other criminal cells, but rather - on its own structure. In five states - Jalisco, Colima, Guanajuato, Nayarit and Veracruz - it is the only criminal group. Their presence is noticeable in Morelos, Guerrero and Michoacán. Those areas are actively claimed by rival cartels" ${ }^{\prime \prime}$. Official data register presence of the organized crime in 19 of 31 Mexican states. Nine of those states have at least two opposing drug cartels in their territory. The most problematic are the states of Morelos and Guerrero, where there are even three rival groups: the Beltran Leyva, La Familia Michoacana and Jalisco Nueva Generación.

\section{Table 2. Spatial Dimension of Mexican Cartels}

\begin{tabular}{|l|l|c|}
\hline Criminal Organizations & \multicolumn{1}{|c|}{ States of Mexico } & Number of entities \\
\hline Pacífico & $\begin{array}{l}\text { Sinaloa, Chihuahua, Baja California, Sonora, Durango, } \\
\text { Colima, Jalisco, Nayarit, Quintana Roo, Guerrero, Chiapas, } \\
\text { Yucatán and Campeche. }\end{array}$ & 14 \\
\hline Zetas & $\begin{array}{l}\text { Coahuila, Nuevo León, Veracruz, Tamaulipas, Tabasco, } \\
\text { Quintana Roo, San Luis Potosí, Zacatecas, Guanajuato, } \\
\text { Puebla, Hidalgo and Oaxaca. }\end{array}$ & 12 \\
\hline CDG & $\begin{array}{l}\text { Tamaulipas, Nuevo León, Coahuila, Quintana Roo, Zacate- } \\
\text { cas, San Luis Potosí, Aguascalientes, Guanajuato, Oaxaca } \\
\text { and Morelos. }\end{array}$ & 10 \\
\hline Beltrán Leyva & $\begin{array}{l}\text { Guerrero, Sinaloa, Sonora, Morelos, Nayarit, Estado de } \\
\text { México, Aguascalientes, Chiapas and Oaxaca. }\end{array}$ & 9 \\
\hline Familia Michoacana & $\begin{array}{l}\text { Estado de México, Guerrero, Morelos, Guanajuato, Micho- } \\
\text { acán, Jalisco and Colima. }\end{array}$ & 7 \\
\hline Caballeros Templarios & $\begin{array}{l}\text { Michoacán, Guanajuato, Jalisco, Querétaro, Estado de } \\
\text { México and Guerrero }\end{array}$ & 6 \\
\hline CJNG & Jalisco, Colima, Guanajuato, Michoacán and Veracruz. & 2 \\
\hline Carrillo Fuentes & Chihuahua and Sinaloa. & 2 \\
\hline Arellano Félix & Baja California and Baja California Sur. & \\
\hline
\end{tabular}

Source: [5].

\footnotetext{
${ }^{6}$ Factsheet on Drug Dealers in Mexico. Public Safety Commission of the Senate of the Republic. Second Year of the LX Legislature. February 2008.

7 Attorney General's Office (PGR). National Center for Planning, Analysis and Information for Combating Organized Crime. 30.06.2016. Political Animal. Radiography of narco: Pacific and Jalisco Cartels, they dominate; Templars and Zetas are retracted. Available at: http://www.animalpolitico.com/2016/07/asi-se-reparten-carteles-de-la-droga-en-mexico/ (accessed: 23.02.2017)
} 
We can point out now the states that are: 1) centers of the management and production of drugs (cultivation of opium and marijuana, production of methamphetamine): Sinaloa, Guerrero, Michoacán and Jalisco; 2) centers of the global/local-global transfer (control of the main routes, access to the ports): Colima, Michoacán and Chiapas; and, 3) centers of money-laundering and criminal capital with a local-global dimension: Baja California, Sonora, Chihuahua, Tamaulipas, Distrito Federal (DF), Jalisco and Quintana Roo. The Mexico City remains the center of convergence of all the organizations, either for import and export of drugs andlor for money-laundering.

We can also name the principle drug cartels, acting in some of those states:

- Nuevo Leon: the CDG, the Zetas and the Beltran Leyva.

- Guerrero: the Beltran Leyva, the Zetas and the Pacifico.

- Jalisco: the Pacifico, CJNG, Los Caballeros Templarios and the Familia Michoacana.

The dissemination of the criminal gangs in Mexico is no longer limited to the northern states along the US border. Over the last 10 years they spread to the southern states (Jalisco, Gurrero and even Quintana Roo), showing the ability to resist the government measures. More to that, they started to evolve into mafia structures with their own visible political aspirations.

Table 3. Mexican Cartels centers

\begin{tabular}{|l|l|l|l|}
\hline Organization & $\begin{array}{l}\text { Epicenter of manage- } \\
\text { ment -production local } \\
\text { global }\end{array}$ & $\begin{array}{l}\text { Epicenter of the develop- } \\
\text { ment from globally or } \\
\text { local-global transfer }\end{array}$ & $\begin{array}{l}\text { Epicenter for consolida- } \\
\text { tion and expansion in } \\
\text { local/global dimension }\end{array}$ \\
\hline Purang, Chífico & & $\begin{array}{l}\text { Colima, D.F., Jalisco } \\
\text { Sonora and Sinaloa }\end{array}$ & Sinaloa and Jalisco \\
\hline Los Zetas & $\begin{array}{l}\text { Tamaulipas, Quin- } \\
\text { tana Roo, Tabasco, } \\
\text { Campeche, D.F. }\end{array}$ & $\begin{array}{l}\text { Veracruz, Tamaulipas } \\
\text { and Coahuila }\end{array}$ \\
\hline CDG & Guerrero, Sinaloa & $\begin{array}{l}\text { Tamaulipas, Quintana } \\
\text { Roo }\end{array}$ & $\begin{array}{l}\text { Tamaulipas, Nuevo León, } \\
\text { Coahuila }\end{array}$ \\
\hline Beltrán Leyva & Chiapas, Guerrero, D.F. & $\begin{array}{l}\text { Nuevo León, Morelos } \\
\text { and Guerrero }\end{array}$ \\
\hline Familia Michoacana & Michoacán & Michoacán & Estado de México \\
\hline Caballeros Templarios & Michoacán & Michoacán & Michoacán \\
\hline CJNG & Jalisco & Colima, Jalisco & Jalisco \\
\hline Los Carrillo Fuentes & & Chihuahua and D.F & Chihuahua \\
\hline Los Arellano Félix & & Baja California and D.F & Baja California \\
\hline
\end{tabular}

Source: [5].

Besides the process of convergence of the criminal structures, the states of Jalisco, Michoacán and Guerrero witness now the process of their organizational reconfiguration.

\section{From the drug cartels to mafias}

As it was noted by a recognized expert in the field of criminal organizations, "Mexican drug cartels have already transformed themselves into a mafia, that is to 
say, structures with strict collective rules and hierarchies that do not respond instinctively with violence («if you do not pay, you die»), but follow their proper "codes" and economic strategies. This complexity makes Mexican cartels mature enough to define them as mafias. There can be no mafia without links with politicians, employers, judiciary power; ties that go beyond simple bribery and corruption"8.

It's true that mafias cannot exist without a link with politics and vice versa. Evident links between mafia and politics exceed the traditional methods manu militari with massive human rights violations and the overall violent crime increase. If so, than $t$ the militarization of drug struggle is an evidence of the institutional weakness of the state, and widespread corruption.

In this situation "old institutions - police, courts, prisons, intelligence agencies, parties, and elections - don't work anymore. Indeed, they are clearly corrupt and broken, and very few new institutional mechanisms can be used to replace them.

Moreover, all efforts to reform them, as a rule, can be completely thwarted by institutional corruption and criminal violence. There were of course significant institutional reforms proposed or currently implemented in Mexico at the end of the 2006-2012 term of Felipe Calderón, but the implementation of reforms need a lot of time, and they were not sufficiently implemented to stop the growth of drug trafficking, crime, violence and corruption associated with them" [1, p. 12].

There was a deep contrast between the "war on drugs», declared by F. Calderón, and the refusal to continue the investigations begun CISEN - the Center for Investigation and National Security, a Mexican civil intelligence agency. According to a former senior officer in CISEN, this "war" was a kind of simulation: "during my stay in CISEN, - he noted, - I could see that the corruption of power is precisely one of the sources of organized crime and uncontrolled violence. I realized that more than half of the governors directly or through its partners associated with drug trafficking or at least turn a blind eye to them. The same thing happened with many mayors, councilors and and deputies, both on the local and federal levels. CISEN had data to prove my point, but to my disappointment, nobody used it. My conclusion is that political demands should never dominate the state. Unfortunately, we tend to think first about elections, budgets, balances between parties, etc., before thinking about Mexico as such. Those who govern are not politicians, but they are not Statesmen either." [9, p. 204-208].

The biggest mistake in the "war on drugs» in the decision on the adoption of it into election plans of the "pseudo-president», said F. Calderon. Because after the election he had to proclaim this "The Reason of the State», trying to fight crime in the shortest time and using (quite naturally) the most brutal methods. Among other shortcomings of the President's plan, which finally spoiled everything, we can highlight the following:

\footnotetext{
${ }_{8}^{8}$ Saviano, R. Se escapó un mafioso (A mobster Escaped) (The Lord of the tunnels). El Universal. 20.07.2015. Available at: http://www.eluniversal.com.mx/articulo/nacion/seguridad/2015/07/20/el-chapo-la-fuga-de-un-mafioso\#imagen-1 (accessed: 23.02.2017)
} 
- the mass is a selective approach, where decisions are taken in the absence of or wrong information about the adversary;

- the prevalence of quantity over quality, when they were concentrated fully on the fight against petty crime, while the more serious were simply ignored;

- excessive legislation, when the adoption of new laws was done in detriment to the effective implementation of the old ones;

- abundance of declarations in the absence of results;

- primacy of electoral and political interests over practical matters.

The worst results of a failed campaign, in our opinion, in addition to the complete consolidation and diversification of criminal organizations, are:

- militarization of the public security, when the military got the opportunity to act on the basis of established legal rules;

- introduction of the «united police procedure», which resulted in continuous militarization of state structures;

- arbitral selection and firing of the police personnel, experts, etc. ignoring established procedures;

- excessive international cooperation, particularly with the United States that affect the state sovereignty and the ability of the autonomous action;

- systematic human rights violation during the de facto creating an emergency situation in open contradiction with democratic norms and the "State of law".

Our conclusion is rather simple. In its main features it coincides with the main conclusions after struggling with the Sicilian mafia in Italy. They can be synthesized in a "theory of the two-wheeled wagon". If one wheel is justice (law, police, courts, prisons), and another wheel is civil society (responsible citizens), it is necessary that both wheels move together and with the same speed that the wagon was moving forward, not in a circle [4]. Formulating the necessary synergy between these "wheels", we must put an end to the impunity of the political class - to maintain «zero tolerance» for those politicians who use their se their position for personal or group interests.

The experience of Mexico, confronted with the offensive of the powerful criminal drug and mafia structures in the beginning of the 21 century, should not be overseen by specialists in other countries. The power of the drug and its ability to dispute the authority of the state, is evident enough to be ignored. The "modality" of the liaison "demand - offer", formed along the entire U.S. - Mexico border, is not unique and can be repeated anywhere.

The increase in the drug consumer market and rising demand engenders the emergence of a large number of manufacturers. Some examples of ties can be: Argentina - Brazil, Afghanistan - the Central Asian States - Russia and Burma - China. The "vicious circle" of drug trafficking, violence and corruption must be recognized in all these countries as a full-scale threat to national security, which is already reflected in security doctrines of some of them (Argentina, Brazil).

While speaking about the proper methods of fighting against the organized crime, it should be borne in mind that the Mexican experience 2006 - 2012 proved that in 
this field nothing can be done without complex anti-crime strategy based not on shortterm electoral, political, economic or other considerations, but persistent and continuous elimination of deep rooted socio-cultural and psychological causes of crime.

According to Mexican experts, such strategy to be preemptive, must be based on permanent cooperation of the government, law enforcement agencies with civil society, and not to be limited with slogans of presidential campaignsa. It should represent the collective will and commitment of all Mexicans who are concerned about the problems of their country9.

The contemporary technical means or the professionalization of the law-enforcement structures can and, of course, must help in this task, but not replace it. The same can be said about the problem of "violent" or "non-violent" methods of struggle. It is quite obvious that only the rational combination of both methods depending on each specific case can be justified as the proper measure in this difficult struggle. In this respect the Mexican people will have to ask a lot of questions to their authorities, the police and the whole prison system of the country.

\section{References}

1. Bagley, B. Drug Trafficking and Organized Crime in the Americas: Major Trends in the Twentyfirst Century. Washington, D.C., Wilson Center, 2012. 22 p.

2. Chumakova, M. Bor 'ba s prestupnost 'yu: uroki dlia Meksiki I dlia Rossii [Struggle with the Criminalty: Lessons for Mexico and for Russia]. Russian International Affairs Council. Available at: http://russiancouncil.ru/inner/?id_4=2990\#topcontent (accessed: 23.02.2017).

3. Góngora J.-A., Moloeznik M.-P. Evolución del crimen transnacional organizado: un enfoque global para su combate. Separate papers. Universidad de Guadalajara (México). 2015. Pp.

4. Leoluca O. Towards a Culture of Legality (The Sicilian experience). Mexico, Metropolitan Autonomous University Publ., 2004. Pp.

5. Martinez Sanchez T. Jalisco Nueva Generación: an Epicenter of the Local-global Drug Trafficking. In: Moloeznik M.- P., Sumano A.R. (Org.) Security and Justice in Jalisco: Scenarios and Proposals. Mexico, University of Guadalajara Publ., 2016. Pp. 202-230.

6. Moloeznik M.-P. Apuntes críticos sobre las márecientes iniciativas de reformas legislativas del Presidente Felipe Calderón Hinojosa

en material de seguridad y modelo policial. Letras Jurídicas. 2011. No. 12. Available at: http://letrasjuridicas.cuci.udg. $\mathrm{mx} / \mathrm{sitio} /$ index.php/revista-numero-12-primaveramarzoseptiembre-de-2010? download $=151$ (accessed: 23.02.2017)

7. O'Nail S.K. Two Nations Indivisible: Mexico, the United States, and the Road Ahead. New York, Oxford University Press Publ., 2013. 264 p.

8. Protsenko A. Meksika: evolutsiya kriminal 'nych klanov [Mexico: The Evolution of the Criminal Clans]. In: Sovremennaya organizovannaya prestupnost: liki, spetsifika y metody protivodeystviya ei v stranakh Latinskoi Ameriki [Contemporary Organized Criminality: Faces, Specifics and the Methods of Fight with it in Latin America]. Moscow, ILA RAN Publ., 2017. pp. (in Russian)

9. Tamez M. Politics and Corruption. Mexico City. 2016. P.?

10. Transnatsional nuy narcobiznes: novaya globalnaya ugroza [Transnational Narcobusiness; a New Global Threat]/ Moscow: ROSSPEN. 2002. 360 p. (In Russian).

\footnotetext{
9 González J. EEUU desbordado por la "crisis humanitaria" de los niños sin papeles. BBC Mundo. 21.06.2014. Available at: http://www.bbc.com/mundo/noticias/2014/06/140620_eeuu_crisis_humanitaria_menores_indocumentados_jg (accessed: 23.02.2017).
} 


\section{About the authors:}

Boris F. Martynov - Professor of the MGIMO University, the Head of the Department of International Relations and Foreign Policy of Russia. av. Vernadskogo 76, Moscow, 119454, Russia.

E-mail: bfmartynoff@gmail.com.

Pablo Marcos Moloeznik - Research Professor (Ph.D), Department of Political Studies, University Center for Social Sciences and Humanities of the University of Guadalajara, Mexico. Guanajuato No. 1045, C.P. 44260. Guadalajara, Jalisco, Mexico. E-mail: vestnik@mgimo.ru.

\section{КРИМИНАЛЬНЫЙ СЦЕНАРИЙ ДЛЯ МЕКСИКИ}

Marcos P. Moloeznik, Б.Ф. Мартынов

DOI 10.24833/2071-8160-2017-2-53-184-194

Московский государственный институт международных отношений (университет) МИД России Центр социально-гуманитарных наук Университета Гвадалахары

В статье излагается состояние проблемы оргпреступности в современной Мексике, связанной с деятельностью криминальных преступных кланов, которые зародились в этой стране ещё в 30-е гг. прошлого столетия. Существование границы между Мексикой и США протяженностью в 3200 км и постоянного спроса на наркотики в соседней стране обусловливает постоянный приток на американский рынок нелегальных мигрантов и наркотиков из Мексики, которая «в обмен» продолжает получать партии американского огнестрельного оружия. Растущая материальная и финансовая «подпитка» криминальных банд ведёт к попыткам сращивания их с местными органами власти, при том что организационные структуры криминального бизнеса распространяются не только по обе стороны от американо-мексиканской границы, но и продвигаются южнее - на ещё не охваченные ими штаты Мексики, а также на государства Центральной Америки. В статье выделяются наиболее «освоенные» криминалитетом штаты этой страны, анализируется степень его воздействия на политическую жизнь государства, методы и приемы «мимикрии» оргпреступности под давлением правоохранительных структур (деление, разукрупнение).

Борьба, которая велась с оргпреступностью в Мексике в период 2006-2012 гг., не оправдала себя, поскольку она не опиралась на чёткое знание реалий этой страны, использовала исключительно силовые методы и почти не задействовала силы гражданского общества. Кроме того, она лишь увеличила уровень насилия в стране и способствовала росту коррупции в рядах правоохранителей. Многие её составляющие носили ярко выраженный «предвыборный» характер, направленный на привлечение избирателя обещанием «скорой и решительной победы» над криминалитетом. Ожидать такой победы можно лишь в случае терпеливой и последовательной борьбы с оргпреступностью всех здоровых сил мексиканского общества на основе выработки долгосрочной стратегии такой борьбы, которая предполагала бы отказ от использования односторонних, а также политизированных и конъюнктурных подходов.

Ключевые слова: мексиканская организованная преступность, латиноамериканские наркокартели, незаконная миграция, наркотрафик, американо-мексиканские отношения. 


\section{References}

1. Bagley B. Drug Trafficking and Organized Crime in the Americas: Major Trends in the Twenty-first Century. Washington, D.C., Wilson Center, 2012. 22 p.

2. Чумакова М. Борьба спреступностью: уроки Мексики для России / РСМД. Режим доступа: http://russiancouncil. $\mathrm{ru} /$ analytics-and-comments/analytics/borba-s-prestupnostyu-uroki-meksiki-dlya-rossii (дата обращения: 23.02.2017).

3. Góngora J.-A., Moloeznik M.-P. Evolución del crimen transnacional organizado: un enfoque global para su combate. Separate papers. Universidad de Guadalajara (México). 2015.

4. Leoluca O. Towards a Culture of Legality (The Sicilian experience). Mexico, Metropolitan Autonomous University Publ., 2004.

5. Martinez Sanchez T. Jalisco Nueva Generación: an Epicenter of the Local-global Drug Trafficking. In: Moloeznik M.- P., Sumano A.R. (Org.) Security and Justice in Jalisco: Scenarios and Proposals. Mexico, University of Guadalajara Publ., 2016. Pp. 202-230.
6. Moloeznik M.-P. Apuntes críticos sobre las márecientes iniciativas de reformas legislativas del Presidente Felipe Calderón Hinojosa en material de seguridad y modelo policial. Letras Jurídicas. 2011. No. 12. Режим доступа: http://letrasjuridicas.cuci.udg. $\mathrm{mx} / \mathrm{sitio} / \mathrm{index} . \mathrm{php} / \mathrm{re}$ vista-numero-12-primavera-marzoseptiembre-de-2010?download=151 (дата обращения: 23.02.2017)

7. O'Nail S.K. Two Nations Indivisible: Mexico, the United States, and the Road Ahead. New York, Oxford University Press Publ., 2013. 264 p.

8. Проценко А. Мексика: эволюция криминальных каналов // Современная организованная преступность: лики, специфика и методы противодействия ей в странах Латинской Америки. М.: ИЛА РАН, 2017.

9. Tamez M. Politics and Corruption. Mexico City. 2016.

10. Транснациональный наркобизнес. Новая глобальная угроза. М.: РОСПЭН, 2002. 360 с.

\section{6 авторах:}

Борис Фёдорович Мартынов - профессор МГИМО МИД России, заведующий кафедрой международных отношений и внешней политики. 119454, Москва, пр. Вернадского, д.76, Россия.

Молоезник Маркос Пабло - профессор кафедры политических наук Университета Гвадалахары (Мексика), Центр социальных и гуманитарных наук. Халиско г. № 1045, С. П. 44260. Гвадалахара, Халиско, Мексика. 